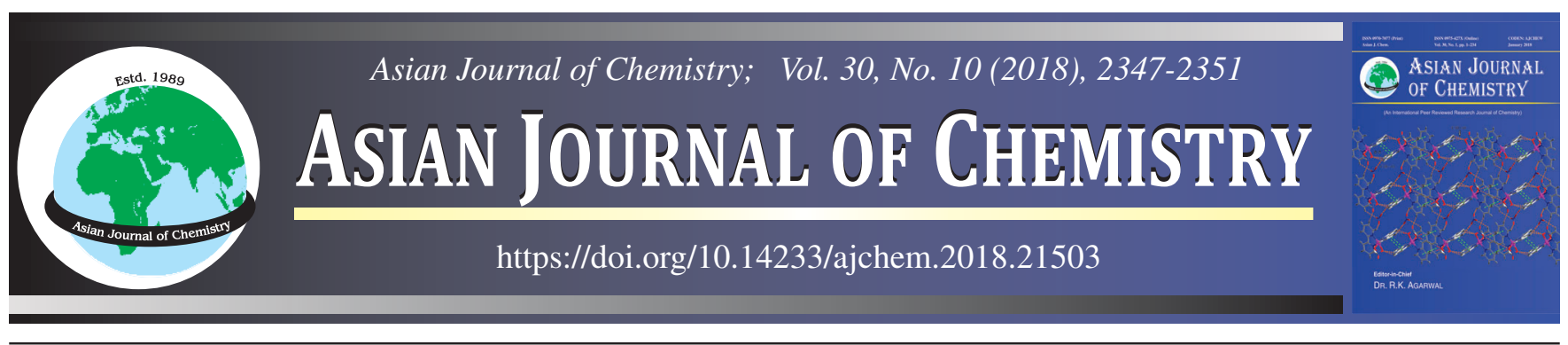

\title{
Atomic Layer Deposition of Zinc Oxide on Single and Multi-Walled Carbon Nanotubes and its Application in Solar Cells Simulation
}

\author{
Rafah M. Thyab, Mahmoud H. Hadwan and Abbas J. Atiyah*
}

Department of Chemistry, College of Science, University of Babylon, Hilla 51002, Iraq

*Corresponding author: E-mail: abbaslafta2009@yahoo.com

Received: 7 June 2018; Accepted: 23 July 2018;

Published online: 31 August 2018;

AJC-19072

This work involves direct doping of $\mathrm{Zn}\left(\mathrm{CH}_{3} \mathrm{COO}\right)_{2} \cdot 2 \mathrm{H}_{2} \mathrm{O}$ with both single-walled carbon nanotubes (SWCNTs) and multi-walled carbon nanotubes (MWCNTs) at $60^{\circ} \mathrm{C}$. The produced composites of ZnO/SWCNTs and ZnO/MWCNTs were investigated using X-rays diffraction patterns, atomic force microscopy and Fourier transform infrared spectroscopy. From the results, it was found that ZnO was deposited uniformly with both of single and multi-walled carbon nanotubes. It was also found that $\mathrm{ZnO}$ in the prepared composites does not lack its crystallinity as it was concluded from XRD patterns for the prepared composites. The activity of the prepared composites was investigated in solar cells simulations via applying these composites as a photocathode for a solar cell. The obtained results of simulated solar cells showed that used $\mathrm{ZnO} / \mathrm{MWCNT}$ s composite showed higher fill factor, maximum current $\left(\mathrm{I}_{\max }\right)$, maximum voltage $\left(\mathrm{V}_{\max }\right)$ and lower open circuit voltage $\left(\mathrm{V}_{\mathrm{oc}}\right)$ in comparison with $\mathrm{ZnO} / \mathrm{SWCNT}$ s composite.

Keywords: Carbon Nanotubes, Solar cells, Zinc oxide, Composite materials.

\section{INTRODUCTION}

Natural carbon is present in $s p^{2}$ hybridization, can form an assortment of stunning structures. A side from the notable graphite, carbon can manufacture a honeycomb nuclear game plan. In the first place such structure to be found was $\mathrm{C}_{60}$ atom by Kroto et al. [1]. Despite the fact that different carbon confines were examined, it was just in 1991, when Iijima [2] noted blue tubular carbon structures. The nanotubes comprised of upto a few many graphite shells (supposed multi-walled carbon nanotubes (MWCNTs)) with nearby shell division of $0.34 \mathrm{~nm}$, distances across of $1 \mathrm{~nm}$ and vast length/measurement proportion. After two years, Iijima and Ichihashi [3] and Bethune et al. [4] combined single-walled carbon nanotubes (SWCNTs). These days, MWCNTs and SWCNTs are created essentially by three strategies: (a) circular segment release, (b) laser-removal and (c) reactant development. The combined nanotube tests are portrayed by methods for Raman, electronic and optical spectroscopies $[5,6]$. Imperative data are inferred by mechanical, electrical and warm measurements. The test information is investi-gated via examination with the consequences of hypothetical models [7-12].
The materials generally utilized as a part of gas sensors are semiconductor metal oxides,vapor-touchy polymers and different permeable planned materials considered as permeable silicon. The desorption and adsorption of gas atoms on detecting materials is the normal gas sensors' standard. It is straightforward that the affectability can increase altogether by improving the contact interfaces between detecting materials [1316]. Single walled carbon nanotubes are formed by making a barrel shaped state of graphene having breadth of 0.4 to 2.0 $\mathrm{nm}$. Multi-walled carbon nanotubes is a blend of a few layers of SWCNTs that are erratic together [17]. The distance across for both SWCNTs and MWCNTs is between a small amount of one of nanometer to several nanometers. The length of both can be up to a few centimeters $[18,19]$.

Solar cells have extraordinary potential applications as an elective energy source in view of huge measure of accessible energy and its dispersed nature that may empower an appropriated control age lattice [20]. In any case, for sun based vitality to be financially savvy on an utility scale, the cost of procurement, establishment, operation and maintenance over the lifetime of sun oriented board for every $\mathrm{kWh}$ created must contrast positively with current power age innovation, which

This is an open access journal, and articles are distributed under the terms of the Creative Commons Attribution-NonCommercial 4.0 International (CC BY-NC 4.0) License, which allows others to copy and redistribute the material in any medium or format, remix, transform, and build upon the material, as long as appropriate credit is given and the new creations are licensed under the identical terms. 
for petroleum derivative based age is 0:03 $(0.05 \$ / \mathrm{kWh})$ [21]. Enhancements are being made to solar cells to (a) increment the productivity, and (b) bring down the cost. For example, sun powered concentrators are being created that concentration of sun oriented light reflecting off a substantial mirror on a solar cell with a littler surface territory. Multi-intersection gadgets are being produced that utilization intersections between materials with various band holes to catch a more noteworthy number of photons and utmost loss of abundance photon vitality when the energized high-energy electron unwinds to the Fermi level.

Carbon nanotubes are chemically inert and show promising characteristics as counter electrodes [22-25]. The present work involves synthesis of composites of $\mathrm{ZnO} / \mathrm{SWCNTs}$ and $\mathrm{ZnO} / \mathrm{MWCNTs}$ and their application in solar cell phenomenon.

\section{EXPERIMENTAL}

Single-walled carbon nanotube and multi-walled carbon nanotube: In this study, single walled carbon nanotubes (CNTs) was purchased from Grafton cheap tubes with outer diameter 1$4 \mathrm{~nm}$, length of $0.5-2.0 \mu \mathrm{m}$ and purity $>90 \%$. Multi-walled carbon nanotubes purchased from the same company with outer diameter of $13-18 \mathrm{~nm}$, length of 3-30 $\mu \mathrm{m}$ and purity $99 \%$.These materials were used as starting materials in the preparation of composites by combination with zinc oxide nanoparticles.

Preparation of $\mathrm{ZnO}$ nanoparticals: $\mathrm{ZnO}$ nanoparticles were prepared as a colloidal by self-assembly method. All materials which used in synthesis process supplied from Fluka company. $\mathrm{Zn}\left(\mathrm{CH}_{3} \mathrm{COO}\right)_{2} \cdot 2 \mathrm{H}_{2} \mathrm{O}(0.01 \mathrm{M})$ solution was prepared by dissolving zinc acetate $(1.25 \mathrm{mmol})$ in $125 \mathrm{~mL}$ of methanol under vigorous stirring at $60^{\circ} \mathrm{C}$. Then this solution was made basic by adding $0.03 \mathrm{M}$ of $\mathrm{KOH}$ solution which was prepared by dissolving 2 $\mathrm{mmol}$ of $\mathrm{KOH}$ in $65 \mathrm{~mL}$ of methanol. Potassium hydroxide solution was added dropwise to zinc acetate solution and the reaction mixture was stirred for $2 \mathrm{~h}$ at $60^{\circ} \mathrm{C}$ [26]. Then the obtained solid was separated using centrifuge and stored in ethanol for $2 \mathrm{~h}$. It was finally separated from ethanol by filteration and dried in oven at $80^{\circ} \mathrm{C}$ for $4 \mathrm{~h}$ and then the sample was annealed at $300{ }^{\circ} \mathrm{C}$ for $2 \mathrm{~h}$.

Preparation of $\mathrm{ZnO} / \mathrm{SWCNTs}$ and $\mathrm{ZnO} / \mathrm{MWCNTs}$ composites: Single-/multi-walled carbon nanotubes $(0.1 \mathrm{~g})$ was mixed with zinc acetate $(50 \%)$ and stirred for $1 \mathrm{~h}$. Then $\mathrm{KOH}$ was added gradually at $60^{\circ} \mathrm{C}$ for $3 \mathrm{~h}$ with continuous stirring at this temperature. The obtained mixture was then separated and dried at $80{ }^{\circ} \mathrm{C}$ for overnight and calcinated at $350{ }^{\circ} \mathrm{C}$ in furnace for $2 \mathrm{~h}$.The obtained materials were investigated using $\mathrm{X}$-rays diffraction, atomic force microscopy and Fourier transform infrared spectroscopy.

Fabrication of photoelectrodes and DSSCs: To fabricate the solar cell $0.01 \mathrm{~g}$ of single-/multi-walled carbon nanotubes mixed with few drops of dionized water, and then it coated carefully on indum tin oxide (ITO) glass substrate as cathode. To prepare photoanode, $\mathrm{TiO}_{2}$ was dissolved in $10 \mathrm{~mL}$ of deionized water containing few drops of acetic acid. The obtained mixture was coated on the indum tin oxide glass and then annealed at $500^{\circ} \mathrm{C}$ for $3 \mathrm{~h}$. The photoanode was immersed in N719 dye for $24 \mathrm{~h}$. The cell assembling was performed by adding a few drops of $\mathrm{KI} / \mathrm{I}_{2}$ electrolyte on the photoanode and fixed both electrodes. The current-voltage (I-V) characteristics of solar cell was found using a solar simulator illumination source of intensity $100 \mathrm{~mW} \mathrm{~cm}^{-2}$ [27,28].

Powder X-rays diffraction: Crystalline phase pattern for the prepared composites was investigated using powder X-rays diffractometer type Siemens D500 with a $\mathrm{CuK}_{\alpha} \mathrm{X}$-ray source $(1.5418 \AA)$. The working voltage and current for X-rays was $40 \mathrm{kV}$ and $40 \mathrm{~mA}$, respectively. The scan range of $2 \theta=10-80^{\circ}$.

Atomic force microscopy: Surface morphology of the prepared composites was investigated using atomic force microscopy type SPM-AA3000 Atomic Force Microscope Contact Mode Angstrom Advanced INC., 2005, USA. The energy-dispersive X-ray spectroscopy (EDX) used to determine the elemental percentage in prepared materials.

Fourier transform infrared spectroscopy: Surface functional groups of prepared materials were conducted using Fourier transform infrared spectrometer (Perkin-Elmer company, England). The spectra were recorded in the range of wavenumbers from $4000-400 \mathrm{~cm}^{-1}$.

Activity of prepared composites in solar cell applications: The activity of both prepared composites $\mathrm{ZnO} / \mathrm{SWCNTs}$ and $\mathrm{ZnO} / \mathrm{MWCNTs}$ was investigated via using them as a photocathode in solar cell fabrication. The photocathode was immersed in N719 dye solution as a reference standard dye. The currentvoltage (I-V) characteristics of solar cell was found using a solar simulator illumination source of intensity $100 \mathrm{~mW} \mathrm{~cm}^{-2}$ $[27,28]$.

\section{RESULTS AND DISCUSSION}

$\mathrm{X}$-Rays diffraction for $\mathrm{ZnO}$ /CNTs composites: Crystal structure of prepared composites $\mathrm{ZnO} / \mathrm{SWCNTs}$ and $\mathrm{ZnO} /$ MWCNTs was investigated using XRD diffractometer and the obtained patterns are shown in Fig. 1. From these patterns, it can be seen that peaks of both CNTs and $\mathrm{ZnO}$ are appeared in these patterns. The peak around $26.0^{\circ}$ is assigned to characteristic graphite peak which is related to the presence of tubular structure of the carbon atoms in the sample with (002) planes. The peaks near $44.4^{\circ}$ and $47.3^{\circ}$ are related to the (101) and (004) planes of nanotube structure, respectively $[29,30]$. The peaks around $33.5^{\circ}$ and $35.4^{\circ}$ are assigned to the (111) and (222) planes, respectively of $\mathrm{Fe}$ substrate, which was used as catalyst for the precipitation methods [30]. Other peaks correspond to $\mathrm{ZnO}$ are $31.8^{\circ}, 34.3^{\circ}, 36.8^{\circ}, 47.4^{\circ}, 56.2^{\circ}, 62.66^{\circ}, 68^{\circ}$ and $77^{\circ}$. These peaks are corresponded to the planes of wurtzite zinc oxide. Generally, these patterns confirm exsitance of both $\mathrm{ZnO}$ and CNTs in the prepared composites and in general these patterns

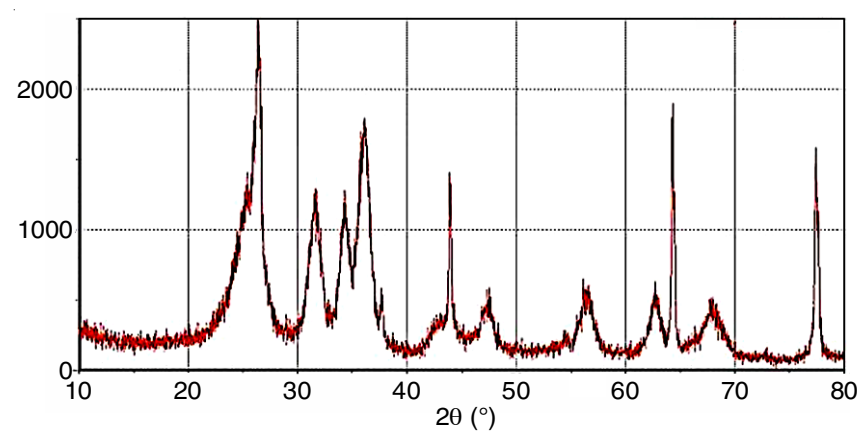

Fig. 1. XRD patterns of $\mathrm{ZnO} / \mathrm{CNTs}$ composite 

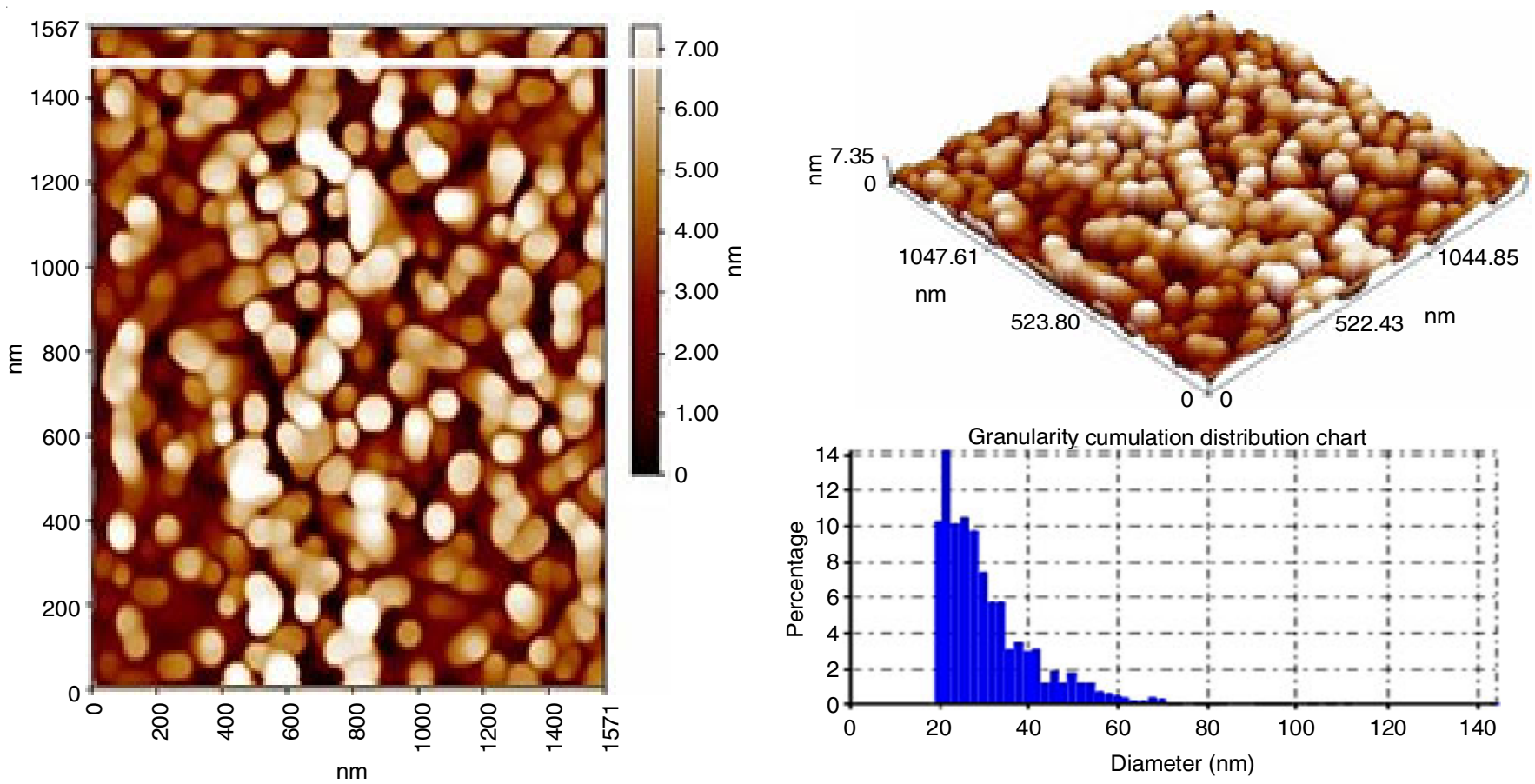

Fig. 2. AFM 2D, 3D views and particle size distribution of $\mathrm{ZnO}$ composites

are almost identical for both composites $\mathrm{ZnO} / \mathrm{SWCNTs}$ and ZnO/MWCNTs.

Atomic force microscopy and scanning electron microscopy: Morphology of both $\mathrm{ZnO}, \mathrm{ZnO} / \mathrm{SWCNTs}$ and $\mathrm{ZnO} /$ MWCNTs was investigated using both AFM and SEM techniques. AFM images for $\mathrm{ZnO}$ nanoparticles are presented in Fig. 2. From these images, $\mathrm{ZnO}$ have homogeneous granular particles with average particles ranged from 20-40 nm.

$\mathrm{ZnO} / \mathrm{SWCNTs}$ composite showed improvement in morphology of the composite with increase of diameter of produced CNTs in the obtained composite around $40 \mathrm{~nm}$ (Fig. 3). The results are presented in Table-1. While ZnO/MWCNTs composite showed an improvement in the morphology of composite with increase of diameter of the produced CNTs composite around $42 \mathrm{~nm}$ (Fig. 4). The obtained results are shown in Table-2.

Energy dispersive X-rays (EDX) analysis of composites: Microelemental analysis of ZnO/SWCNTs and ZnO/MWCNTs composites was investigated using EDX analysis. In general EDX analysis for both prepared composites are almost showed the same microelemental analysis. The results are presented in Figs. 5 and 6. Results showed that the main elements in the prepared composites contains carbon, oxygen, zinc, which are clearly present in the spectrum. However, presence of hydrogen

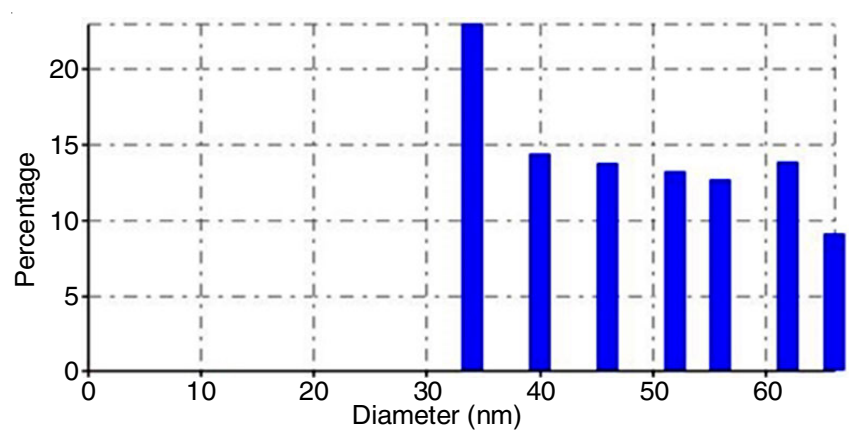

Fig. 3. Granularity cumulation distribution for $\mathrm{ZnO} / \mathrm{SWCNTs}$ composite

\begin{tabular}{ccc}
\multicolumn{3}{c}{ TABLE-1 } \\
GRANULARITY DISTRIBUTION \\
FOR ZnO/SWCNTs COMPOSITE \\
\hline Diameter (nm) & Volume (\%) & Cumulation (\%) \\
\hline 34.00 & 22.94 & 22.94 \\
40.00 & 14.42 & 37.35 \\
46.00 & 13.78 & 51.13 \\
52.00 & 13.24 & 64.37 \\
56.00 & 12.69 & 77.06 \\
62.00 & 13.87 & 90.93 \\
66.00 & 9.07 & 100.00 \\
\hline
\end{tabular}

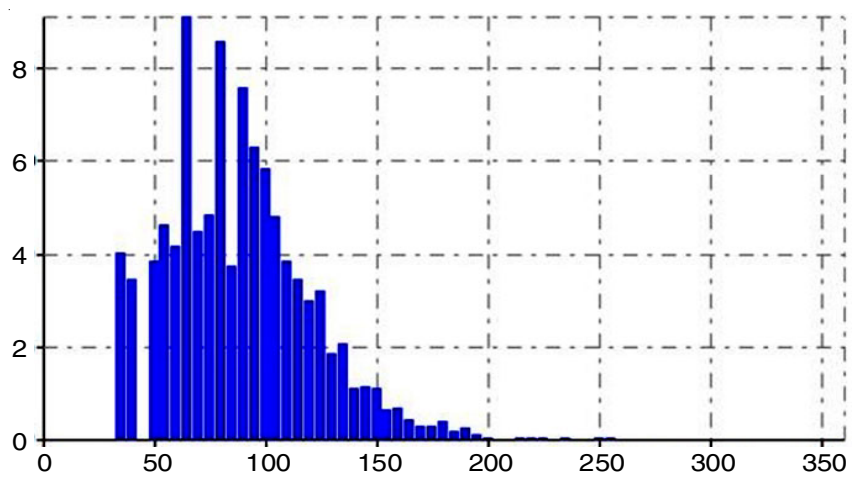

Fig. 4. Granularity cumulation distribution for $\mathrm{ZnO} / \mathrm{MWCNTs}$ composite

\begin{tabular}{ccc}
\multicolumn{3}{c}{ TABLE-2 } \\
\multicolumn{3}{c}{ GRANULARITY CUMULATION DISTRIBUTION } \\
FOR ZnO/ MWCNTs COMPOSITE \\
\hline Diameter $(\mathrm{nm})$ & Volume $(\%)$ & Cumulation $(\%)$ \\
\hline 35.00 & 4.03 & 4.03 \\
40.00 & 3.46 & 7.50 \\
50.00 & 3.84 & 11.33 \\
115.00 & 3.46 & 82.63 \\
120.00 & 3.00 & 85.63 \\
125.00 & 3.20 & 88.82 \\
190.00 & 0.26 & 99.40 \\
195.00 & 0.13 & 99.54 \\
200.00 & 0.07 & 99.60 \\
\hline
\end{tabular}




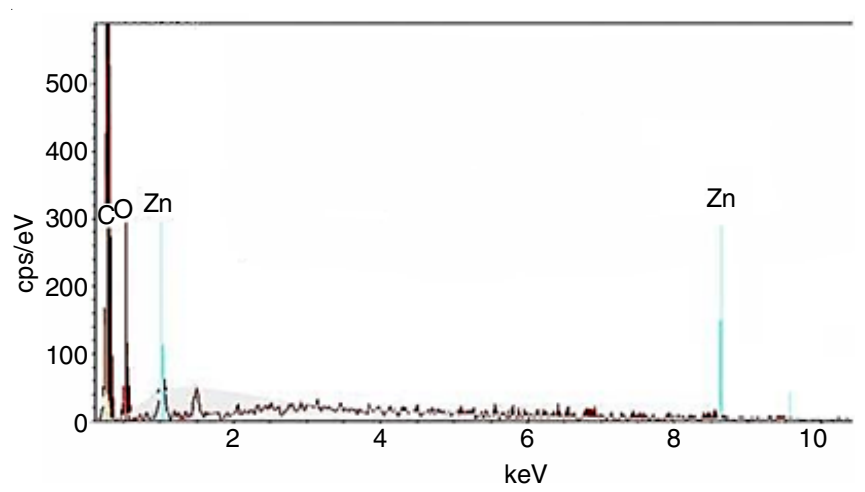

Fig. 5. EDX micro elemental analysis for $\mathrm{ZnO} / \mathrm{SWCNTs}$

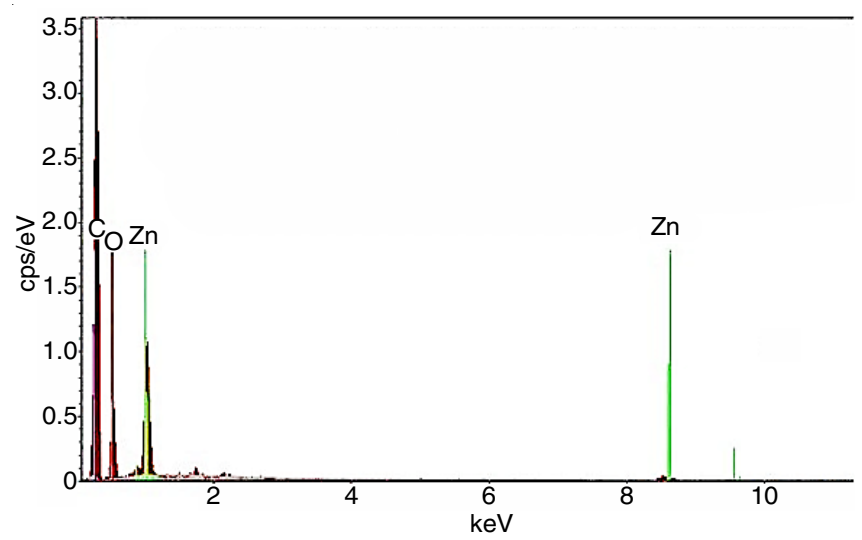

Fig. 6.

with these results is probably due to the atmospheric humidity [31,32]. No other elements are present which refers to the high purity of this prepared composite.

Fourier transform infrared spectroscopy (FTIR): The bands in the range of $1200-1000 \mathrm{~cm}^{-1}$ are related to the presence of $\mathrm{CO}$ groups in the composites. The bands around 1380-1370 $\mathrm{cm}^{-1}$ are assigned to bend vibration of $-\mathrm{CH}_{3}$ and $-\mathrm{CH}_{2}$ groups. The band around $1700 \mathrm{~cm}^{-1}$ is a characteristic peak of carbonyl group. The bands in the range $600-400 \mathrm{~cm}^{-1}$ are related to the characteristic peak of metal oxygen bond (Zn-O) bond (Fig. 7). The bands around $800-600 \mathrm{~cm}^{-1}$ is assigned to $\mathrm{C}=\mathrm{C}$ vibrations

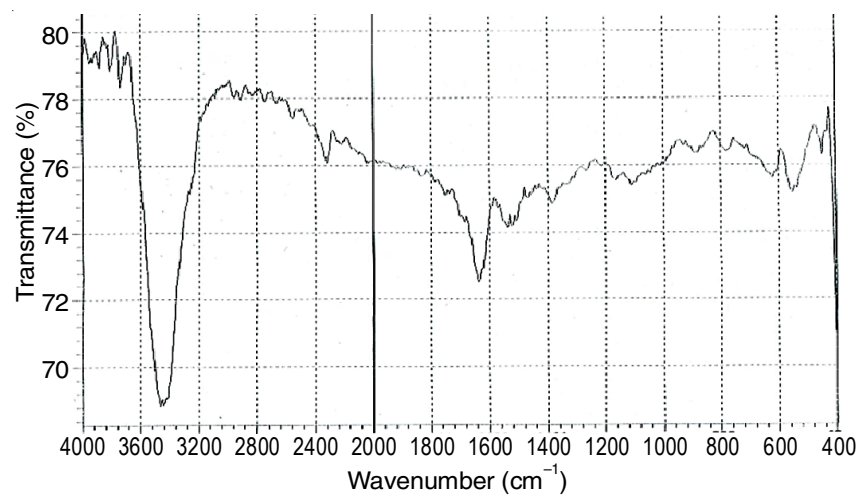

Fig. 7. FTIR spectra for $\mathrm{CNTs} / \mathrm{ZnO}$ composites
[33]. The bands at around $3400 \mathrm{~cm}^{-1}$ is assigned to vibration stretching of $\mathrm{OH}$ groups. The bands in the range 3000-2800 $\mathrm{cm}^{-1}$ can be related to stretching vibration modes of $\mathrm{CH}-\mathrm{CH}$ aliphatic bond at the surface. The band around $1651 \mathrm{~cm}^{-1}$ is related to $\mathrm{C}=\mathrm{C}$ aromatic group and the band around $1670 \mathrm{~cm}^{-1}$ is assigned to stretching of $\mathrm{C}=\mathrm{O}$ bond $[34,35]$. Also appearance of peak around $1626 \mathrm{~cm}^{-1}$ is assigned to $\mathrm{C}=\mathrm{C}$ aromatic bond.

Solar cell activity of composites: The activity of $\mathrm{ZnO} /$ SWCNTs and ZnO/MWCNTs composites in the efficiency of conversion of solar energy into electricity was investigated and the obtained results are shown in Fig. 8.
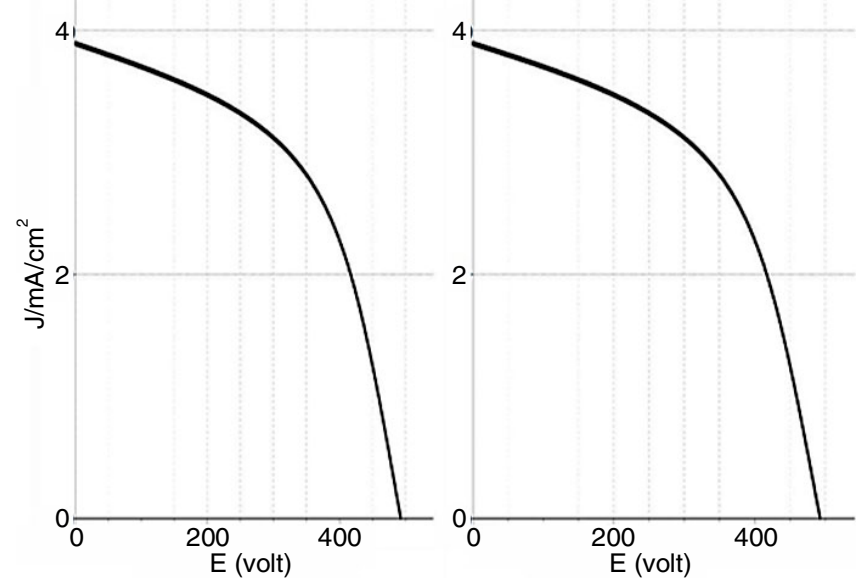

Fig. 8. J-V curves obtained for solar cell simulation using $\mathrm{ZnO} / \mathrm{SWCNTs}$ (left) and $\mathrm{ZnO} / \mathrm{MWCNTs}$ (right) as aphotoelectrode

In general, $\mathrm{ZnO} / \mathrm{MWCNTs}$ composite showed higher fill factor $(\mathrm{FF})$ and lower open circuit voltage $\left(\mathrm{V}_{\mathrm{oc}}\right)$ in comparison with ZnO/SWCNTs composite (Table-3). Also ZnO/MWCNTs showed higher maximum voltage $\left(\mathrm{V}_{\max }\right)$, higher maximum current $\left(\mathrm{I}_{\max }\right)$ and higher conversion efficiency $(\eta \%)$ in comparison with $\mathrm{ZnO} / \mathrm{SWCNTs}$. This is probably due to relatively high carbon content in ZnO/MWCNTs composite in comparison to $\mathrm{ZnO} / \mathrm{SWCNTs}[27,28]$. Carbon nanotubes have very high porosity which enable it to receive high density of electrons and can behave as a sink for electrons.

\section{Conclusion}

This work involves synthesis of composites of $\mathrm{ZnO} /$ SWCNTS and ZnO/MWCNTs successfully. The prepared composites was applied as a photocathode in simulation of solar cells. From the results, ZnO/MWCNTs composite showed a higher activity in term of fill factor, maximum voltage, maximum current and lower $\mathrm{V}_{\mathrm{oc}}$ and $\mathrm{I}_{\mathrm{sc}}$ in comparison of $\mathrm{ZnO} / \mathrm{SWCNTS}$.

\section{ACKNOWLEDGEMENTS}

The authors thank College of Science, University of Babylon, Hilla, Iraq for funding this work as a part of annual research plan for study Year 2017-2018.

TABLE-3

RESULTS OF ENERGY CONVERSION ( $\eta$ \%) AND FULL FACTOR (FF) OF DSSCs ZnO NPs/SWCNTs AND ZnONps/MWCNTs FILMS

\begin{tabular}{cccccccc}
\hline Sample & Photo cathode & $\mathrm{V}_{\mathrm{oc}}(\mathrm{mV})$ & $\mathrm{I}_{\mathrm{sc}}\left(\mathrm{mA} / \mathrm{cm}^{2}\right)$ & $\mathrm{V}_{\max }(\mathrm{mV})$ & $\mathrm{I}_{\max }\left(\mathrm{mA} / \mathrm{cm}^{2}\right)$ & $\eta(\%)$ & $\mathrm{FF}$ \\
\hline $\mathrm{a}$ & ZnO/SWCNTS & 492 & 3.899 & 374.5 & 2.451 & 1.00 & 0.495 \\
$\mathrm{~b}$ & ZnO/MWCNTS & 425 & 5.258 & 387.5 & 3.209 & 1.20 & 0.538 \\
\hline
\end{tabular}




\section{CONFLICT OF INTEREST}

The authors declare that there is no conflict of interests regarding the publication of this article.

\section{REFERENCES}

1. H.W. Kroto, J.R. Heath, S.C. O'Brien, R.F. Curl and R.E. Smalley, Nature, 318, 162 (1985); https://doi.org/10.1038/318162a0.

2. S. Iijima, Nature, 354, 56 (1991); https://doi.org/10.1038/354056a0.

3. S. Iijima and T. Ichihashi, Nature, 363, 603 (1993); https://doi.org/10.1038/363603a0.

4. D.S. Bethune, C.H. Kiang, M.S. de Vries, G. Gorman, R. Savoy, J. Vazquez and R. Beyers, Nature, 363, 605 (1993); https://doi.org/10.1038/363605a0.

5. M.S. Dresselhaus, G. Dresselhaus and R. Saito, Phys. Rev. B, 45, 6234 (1992); https://doi.org/10.1103/PhysRevB.45.6234.

6. M.S. Dresselhaus, G. Dresselhaus and R. Saito, Carbon, 33, 883 (1995); https://doi.org/10.1016/0008-6223(95)00017-8.

7. W.C. Oha, F.J. Zhang, C.S. Lim and M.L. Chen, J. Ceram. Process. Res., 11, 479 (2010).

8. C. Darnault, K. Rockne, A. Stevens, G.A. Mansoori and N. Sturchio, Water Environ. Res., 77, 2576 (2005); https://doi.org/10.2175/106143005X54632.

9. F. Bundy, Physica A, 156, 169 (1989); https://doi.org/10.1016/0378-4371(89)90115-5.

10. M. Kumar and Y. Ando, J. Nanosci. Nanotechnol., 10, 3739 (2010); https://doi.org/10.1166/jnn.2010.2939.

11. A.G. Rinzler, J.H. Hafner, P. Nikolaev, P. Nordlander, D.T. Colbert, R.E. Smalley, L. Lou, S.G. Kim and D. Tomanek, Science, 269, 1550 (1995); https://doi.org/10.1126/science.269.5230.1550.

12. G. Che, B.B. Lakshmi, E.R. Fisher and C.R. Martin, Nature, 393, 346 (1998); https://doi.org/10.1038/30694.

13. B. Gao, A. Kleinhammes, X.P. Tang, C. Bower, L. Fleming, Y. Wu and O. Zhou, Chem. Phys. Lett., 307, 153 (1999); https://doi.org/10.1016/S0009-2614(99)00486-8.

14. A.C. Dillon, K.M. Jones, T.A. Bekkedahl, C.H. Kiang, D.S. Bethune and M.J. Heben, Nature, 386, 377 (1997); https://doi.org/10.1038/386377a0.

15. A. Bachtold, P. Hadley, T. Nakanishi and C. Dekker, Science, 294, 1317 (2001); https://doi.org/10.1126/science.1065824.

16. P.C. Collins, M.S. Arnold and P. Avouris, Science, 292, 706 (2001); https://doi.org/10.1126/science.1058782.

17. C. Gao, Z. Guo, J.-H. Liu and X.-J. Huang, Nanoscale, 4, 1948 (2012); https://doi.org/10.1039/c2nr11757f.
18. D.R. Kauffman and A. Star, Angew. Chem. Int. Ed., 47, 6550 (2008); https://doi.org/10.1002/anie.200704488.

19. O. Yu, P. Jing-Cui, W. Hui and P. Zhi-Hua, Chin. Phys. B, 17, 3123 (2008); https://doi.org/10.1088/1674-1056/17/8/059.

20. N.S. Lewis, Science, 315, 798 (2007); https://doi.org/10.1126/science.1137014.

21. J. Goldemberg, T.B. Johansson and D. Anderson, World Energy Assessment: Overview: 2004 update, United Nations Development Programme (2004).

22. J.E. Trancik, S.C. Barton and J. Hone, Nano Lett., 8, 982 (2008); https://doi.org/10.1021/n1071945i.

23. E. Ramasamy, W.J. Lee, D.Y. Lee and J.S. Song, Electrochem. Commun., 10, 1087 (2008); https://doi.org/10.1016/j.elecom.2008.05.013.

24. S. Hwang, J. Moon, S. Lee, D. Kim, D. Lee, W. Choi and M. Jeon, Electron. Lett., 43, 1455 (2007); https://doi.org/10.1049/el:20072867.

25. M. Kang, Y. Han, H. Choi and M. Jeon, Electron. Lett., 46, 1509 (2010); https://doi.org/10.1049/el.2010.2606.

26. C. Pacholski, A. Kornowski and H. Weller, Angewandte Chemie Int., 41, 1188 (2002); https://doi.org/10.1002/1521-3773(20020402)41:7<1188::AIDANIE1188>3.0.CO;2-5

27. Z. Wan, C. Jia, Y. Duan, L. Zhou, Y. Lin and Y. Shi, J. Mater. Chem., 22, 25140 (2012); https://doi.org/10.1039/c2jm34682f.

28. R.Y.-Y. Lin, Y.-S. Yen, Y.-T. Cheng, C.-P. Lee, Y.-C. Hsu, H.-H. Chou, C.-Y. Hsu, Y.-C. Chen, J.T. Lin, K.-C. Ho and C. Tsai, Org. Lett., 14, 3612 (2012); https://doi.org/10.1021/ol301374c.

29. M. Birowska, K. Milowska and J.A. Majewski, Acta Phys. Pol. A, 120, 845 (2011); https://doi.org/10.12693/APhysPolA.120.845.

30. K. Nishimura, N. Okazaki, L. Pan and Y. Nakayama, Jpn. J. Appl. Phys., 43, L471 (2004); https://doi.org/10.1143/JJAP.43.L471.

31. M.-L. Chen, F.-J. Zhang and W.-C. Oh, J. Korean Ceram. Soc., 45, 651 (2008); https://doi.org/10.4191/KCERS.2008.45.1.651.

32. C.S. Chen, T.G. Liu, L.W. Lin, X.D. Xie, X.H. Chen, Q.C. Liu, B. Liang, W.W. Yu and C.Y. Qiu, J. Nanopart. Res., 15, 1295 (2013); https://doi.org/10.1007/s11051-012-1295-5.

33. E.J. Mohammad, A.J. Lafta and S.H. Kahdim, Pol. J. Chem. Technol., 18, 1 (2016); https://doi.org/10.1515/pjct-2016-0041

34. R. Sharma, K. Goyal, A.R. Chattree, T. Baggi and A. Gupta, ISOR J. Appl. Chem., 5, 36 (2013).

35. M. Theodore, M. Hosur, J. Thomas and S. Jeelani, Mater. Sci. Eng. A, 528, 1192 (2011); https://doi.org/10.1016/j.msea.2010.09.095. 